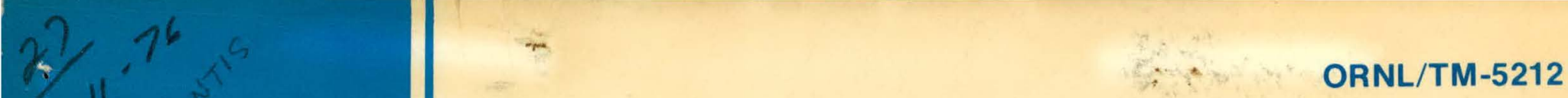

\title{
Flooding Characteristics of Goodloe Packing
}

\author{
J. M. Begovich \\ J. S. Watson
}




\section{DISCLAIMER}

This report was prepared as an account of work sponsored by an agency of the United States Government. Neither the United States Government nor any agency Thereof, nor any of their employees, makes any warranty, express or implied, or assumes any legal liability or responsibility for the accuracy, completeness, or usefulness of any information, apparatus, product, or process disclosed, or represents that its use would not infringe privately owned rights. Reference herein to any specific commercial product, process, or service by trade name, trademark, manufacturer, or otherwise does not necessarily constitute or imply its endorsement, recommendation, or favoring by the United States Government or any agency thereof. The views and opinions of authors expressed herein do not necessarily state or reflect those of the United States Government or any agency thereof. 


\section{DISCLAIMER}

Portions of this document may be illegible in electronic image products. Images are produced from the best available original document. 
Printed in the United States of America: Available from National Technical Information Service

U.S. Department of Commerce

5285 Port Royal Road, Springfield, Virginia 22161

Price: Printed Copy $\$ 4.00$; Microfiche $\$ 2.25$

This report was prepared as an account of work sponsored by the United States Government. Neither the United States nor the Energy Research and Development Administration/United States Nuclear Regulatory Commission, nor any of their employees, nor any of their contractors, subcontractors, or their employees, makes any warranty, express or implied, or assumes any legal liability or responsibility for the accuracy, completeness or usefulness of any information, apparatus, product or process disclosed, or represents that its use would not infringe privately owned rights. 
Contract No. W-7405-eng-26

CHEMICAL TECHNOLOGY DTVISION

J. M. Begovich

J. S. Watson

\title{
AUGUST 1976
}

NOTICE This document contains information of a preliminary nature arud was pitasted primarily for intornal uce at the Dat. Ringe Natinnal Laboratory. It is subject to revision or correction and therefore does not represent a final report.

\author{
OAK RIDGE NATIONAL LABORATORY \\ Oak Ridge, Tennessee 37830 \\ operated by \\ UNION CARBIDE CORPORATION \\ for the \\ ENERGY RESEARCH AND DEVELOPMENT ADMINISTRATION
}

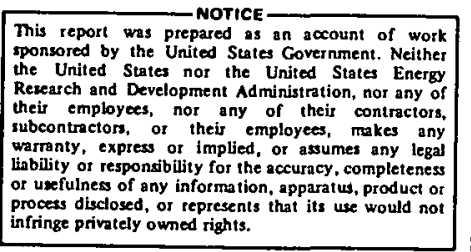

process disclosed, of information, apparatus, product of

infringe privately owned rights. 


\section{THIS PAGE}

\section{WAS INTENTIONALLY \\ LEFT BLANK}


CONTENTS

$\underline{\text { Page }}$

ABSTRACT. . . . . . . . . . . . . . . . . . I

1. IVTRODUCTION. . . . . . . . . . . . . . . . . I

2. EXPERIMENTAL APPARATUS. . . . . . . . . . . . . . . 2

2.1 Goodloe Packing. . . . . . . . . . . . . . . 2

2.2 Original Column. . . . . . . . . . . . . . . 2

2.3 Inverted Column. . . . . . . . . . . . 4

2.4 Column with New Packing. . . . . . . . . . . 4

3. EXPERTMENTAL PROCEDURE. . . . . . . . . . . . . . . . 7

4. RESULTS . . . . . . . . . . . . . . . . 7

4.1 Original Column. . . . . . . . . . . . . . . 7

4.2 Inverted Column. . . . . . . . . . . . . 10

4.3 Column with New Packing. . . . . . . . . . . . II

5. COMPARISON OF EXPERIMENTAL DATA WITH

MANUTACTURER'S CORRELATION. . . . . . . . . . . . . . . I2

6. CONCLUSIONS . . . . . . . . . . . . . . . . 14

7. RETERENCES. . . . . . . . . . . . . . . . . 15

8. APPENDIXES. . . . . . . . . . . . . . . . . . . 17

8.I Appendix A: Size and Density of Goodloe Packing . . . . 19

8.2 Appendix B: Use of the Goodloe Correlation. . . . . . 23

8.3 Appendix C: Pressure Drop Throughout lie Column vs Air Flnw Rate . . . . . . . . . . . . . . 27 
FLOODIIVG CHARACTERISTICS OF GOODLOE PACKIVG

J. M. Begovich

J. S. Watson

ABSTRACT

Experimental flooding dat: for the countercurrent flow of air and water in a $7.62-\mathrm{cm}$-diam glass column filled with Goodloe packing were compared with a correlation reported by the packing manufacturer. Flooding rates observed in this study were as low as one-half those predicted by the correlation. Rearranging the packing by inverting the column and removing some packing segments yielded results similar to the correlation for liquid-to-gas (L/G) mass flow rate. ratios greater than 10, but the experimental flooding curve fell significantly below the correlation at lower L/G ratios. When the column was repacked with new packing, the results were essentially the same as those obtained in the inverted column. Thus, it is believed that a carefully packed column

- is more likely to yield flooding rates similar to those obtained in the new or inverted columns rather than rates predicted by the original correlation.

\section{INTRODUCTION}

Goodloe packing* is used in the absorption column in the Experimental Engineering Section Off-Gas Decontamination Facility. Freliminary tests with this column indicated that the capacity (flooding rate) was significantly less than that predicted by the packing manufacturer's correlation. To assist in evaluating Goodloe packing for the Krypton Absorption in Liquid $\mathrm{CO}_{2}$ (KALC) or other eryngenic sorption processes; an experimental study of flooding rates with Goodloe packing in an air-water system was initiated. The purposes of this study were to compare the flooding curve

\footnotetext{
*Obtained from the Packed Column Co., Div. Metex Corp., Edison, IN. J.
} 
reported by the manufacturer with experimental air-water data and to evaluate the reliability of scale-up using the manufacturer's correlation.

\section{EXPERIMENTAL APPARATUS}

\section{I Goodloe Packing}

Goodloe packing is manufactured from $0.0114-\mathrm{cm}$-diam stainless steel wires, with 12 filaments twisted 0.16 turn per linear centimeter to form a strand. The strands are knitted together to form a tube, which is subsequently flattened to make a double-thickness ribbon approximately $15 \mathrm{~cm}$ wide. The ribbon is crimped, with the creases spaced $0.19 \mathrm{~cm}$ apart and at an angle of $60^{\circ}$ to the center line of the ribbon, and then rolled to fit a specified column diameter. ${ }^{1,2}$ Packing formed in this manner has a surface area per unit volume of about $20 \mathrm{~cm}^{2} / \mathrm{cm}^{3}$ and a void fraction of $95 \%{ }^{3}$

\subsection{Original Column}

A schematic diagram of the experimental column as originally arranged is shown in Fig. I. The $7.62-\mathrm{cm}$-ID glass column contained five pressure taps, each designated by $\mathrm{P}-$, which were connected to air-water manometers to measure pressure gradients. The numbers 1 through 12 refer to packing sections; the size and weight of these sections are listed in Table I (see Appendix A). Process air was introduced at the bottom of the column, and process water was supplied through a distributor cap at the top of the column. Flow rates were metered by rotameters. The water distributor cap was $7.62 \mathrm{~cm}$ in diameter and contained eighty-one $0.32-\mathrm{cm}$ diam holes for the water inlet plus nine $0.95-\mathrm{cm}$-diam holes for the air exit. A 7.0-cm-ID, 7.62-cm-OD rubber 0-ring was located at alternate 
ORNL DWG 74-10876RI

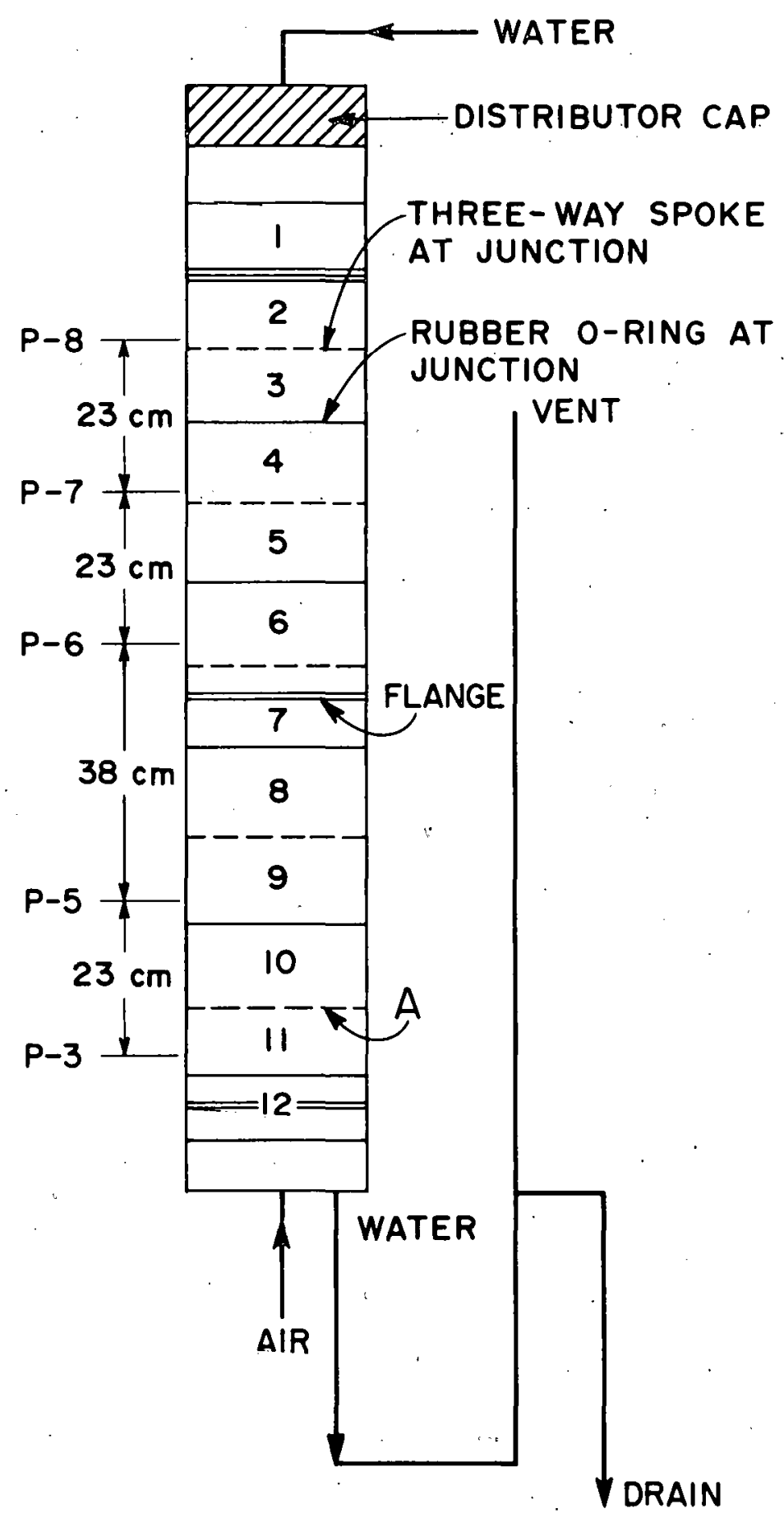

Fig. 1. Initial 7.62-cm-ID colurrir used in flnoding study. 
junctions of the packing sections, while a solid 1.27-cm-diam metal disk with three spokes spaced $120^{\circ}$ apart for positioning was located at each of the remaining junctions. The purpose of these devices was to redistribute any liquid which channeled down the center of the column or along the wall.

\section{3 Inverted Column}

To facilitate the study of local flooding, we inverted the column $180^{\circ}$ so that the apparatus was rearranged as shown in Fig. 2. The positions of the original packing segments in the inverted column are also indicated in this figure; again, the numbers refer to packing sections described in Table 1. This inversion allowed the same packing segments to be observed at two different positions in the column. Packing sections 10 and 11 were subsequently replaced by packing sections 13 and 14 , and the water distributor was changed from a cap to a four-prong distributor so that data could be obtained at high air flow rates, the need for which is discussed later (see sect. 4.2).

\subsection{Column with New Packing}

The effect of apparent packing density was studied by removing the original Goodloe packing and completely repacking the column with new Goodloe packing. Nine packing sections of similar mass were inserted into the column with special care to ensure that axial compression of the packing was minimized; this guaranteed a uniform packing density along the length of the column. Figure 3 shows a schematic drawing of the column and packing arrangement. The individual packing sections are labeled in Fig. 3; the overall dimensions and weight of each section are presented in Table 2 (see Appendix A). 
ORNL-DWG 75-17874

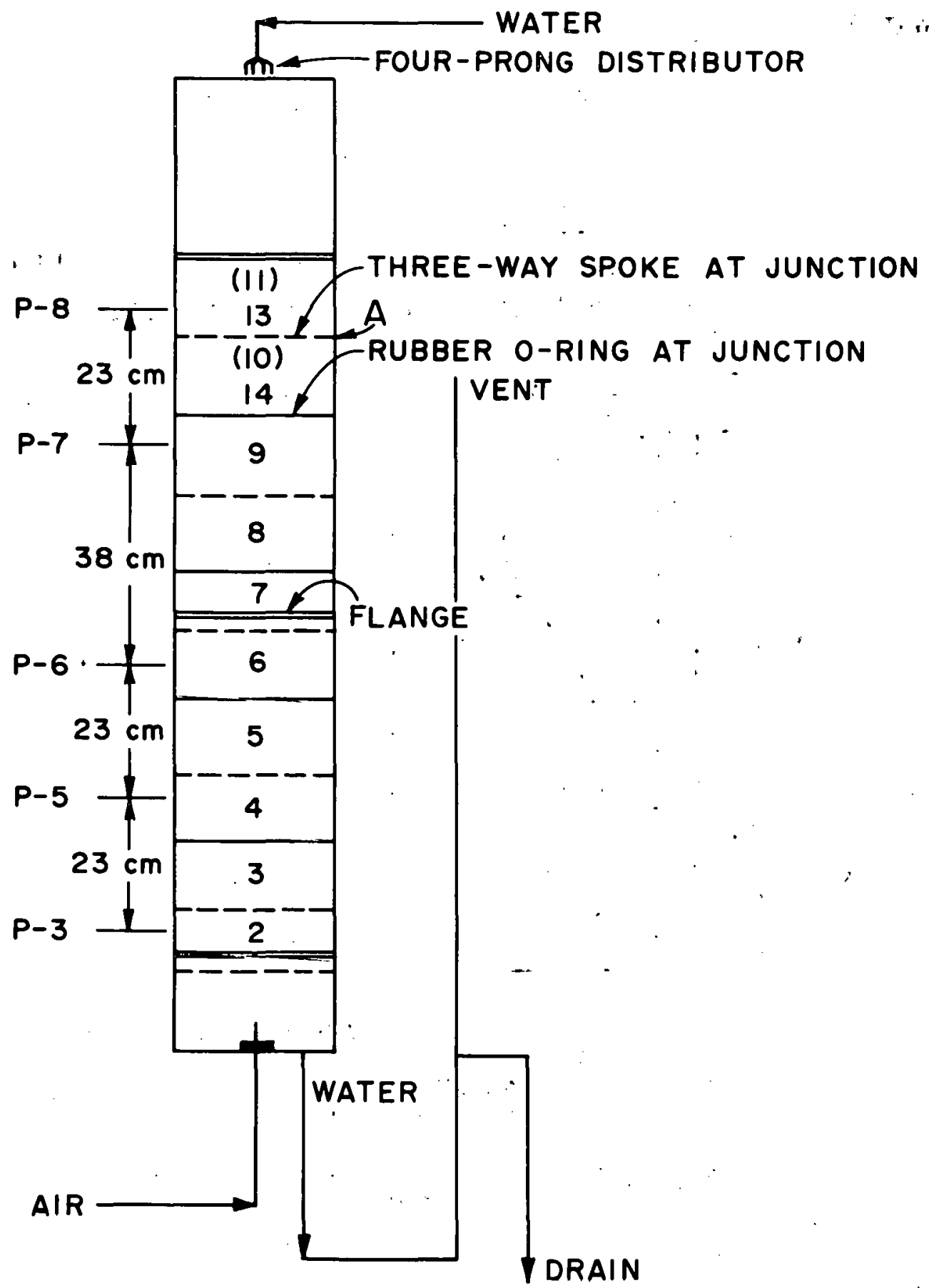

Fig. 2. Inverted column with altered packing arrangement. 


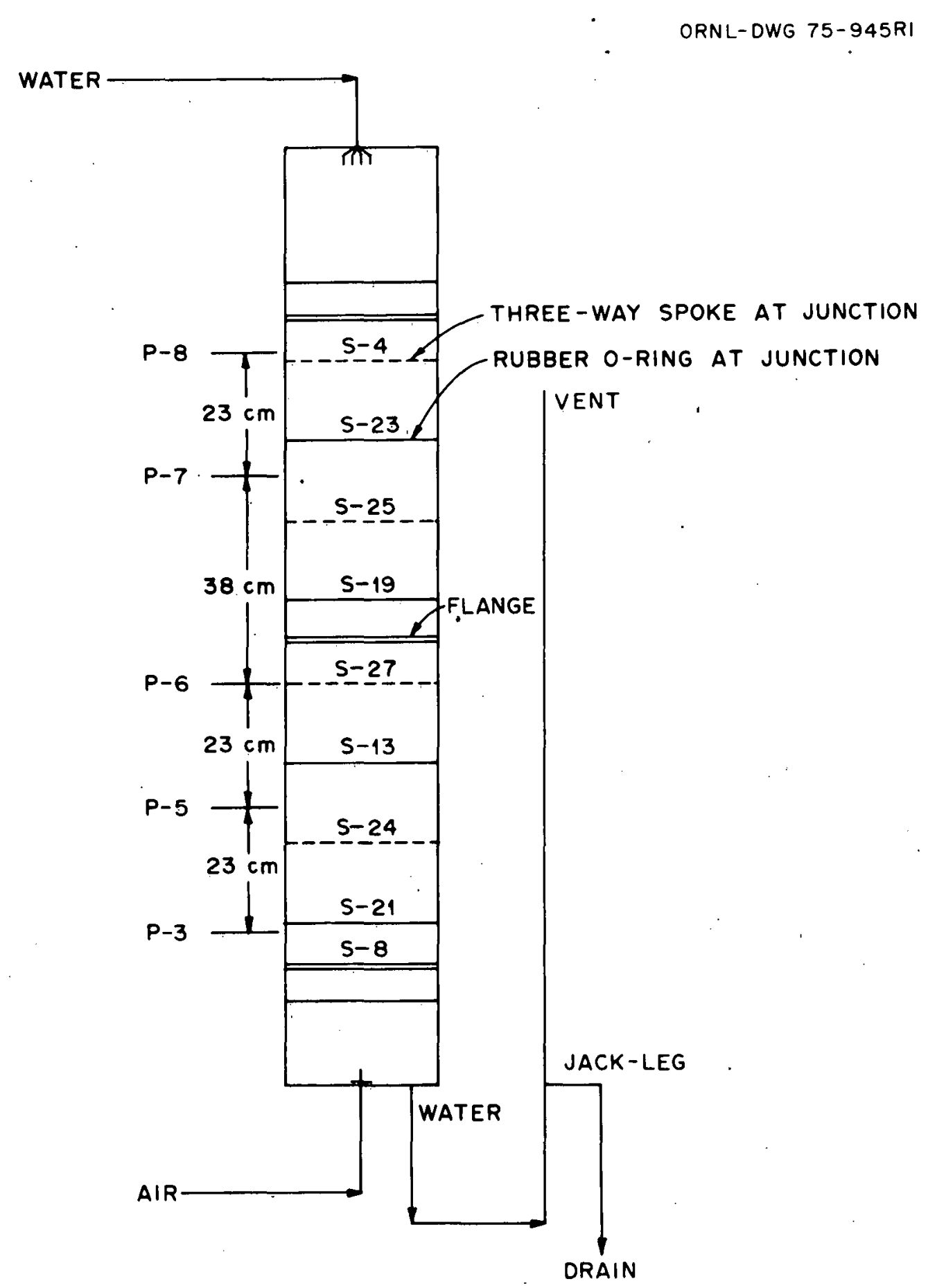

Fig. 3. Inverted column with new packing arrangement. 


\section{EXPERIMENTAL PROCEDURE}

The following procedure was used to make the flooding rate measurements. Before each run, the column was filled with water to wet the packing and subsequently drained. The desired water flow rate was then established and held constant throughout the test; the air flow rate was slowly increased in small incremente until. flooding was observed. The air pressure was read from each of the five manometers. A run time of at least $5 \mathrm{~min}$ was allowed at each air flow rate for the system to reach steady state, as indicated by constant manometer readings; the pressure was recorded at each flow rate until flooding occurred. The column was. considered to be totally flooded when the water level rose to the top of the column.

After a flooding point had been found, the air flow rate was decreased until the column was no longer flooded. A slight decrease in the air flow rate allowed the liquid level to drop below the top of the column, but local flooding remained. Local flooding was characterized by the buildup of water in an isolated section of packing. It was often necessary to decrease the a1r flow rate considerably in order to completely drain the column so that no sections appeared to be flooded.

\section{RESULTS}

\subsection{Orfyinal Column}

With high liquid-to-gas mass flow ratios (L/G $>5$ ), flooding rirst appeared as a local phenomenon. Flooding started each time at the same point in the column, at the junction of two packing sections denoted " $A$ " in Fig. 1. Small increases in the air flow rate caused the liquid leve 
in section 10 (see Fig. I) to rise; however, unless a sufficiently high air flow rate was used, the flooded region did not exceed the height of the one packing section. The column could still be operated at a steadystate condition, as evidenced by constant manometer readings. On sequentially increasing the air flow, a rate was eventually reached which caused the liquid level to proceed completely up the column; the column was then totally flooded.

Figure 4 shows a plot of the pressure drop between pressure taps $\mathrm{P}-3$ and $\mathrm{P}-5$ as a function of gas mass flow rate, $G$. Note that flooding always started at junction $A$, which was located between these taps; thus the pressure drop readings provided a sensitive detection of flooding. Separate curves are shown for different values of $\mathrm{L} / \mathrm{G}_{\max }$, where $G_{\max }$ is the air flow rate at which the column became totally flooded. Note that each curve suddenly breaks upward, with the breakpoint occurring at higher air flow rates as the $\mathrm{L} / \mathrm{G}_{\max }$ ratio decreases (i.e., as the liquid flow rate decreases). The break corresponds to the beginning of local flooding. In the case of the high $L / G_{\max }$ curves $(5.4$ to 23.5$)$, a plateau occurs before the curves again break sharply upward. In this region, liquid was accumulating in section 10 (see Fig. 1) and the liquid level began to rise as the air flow rate was increased. Nevertheless, the liquid level did stabilize at a constant level for each air rotameter setting (i.e., the column was at steady state). The slope of the curve becomes infinite at total flooding, the point at which the air flow rate forces the liquid completely up the column.

For low $L / G_{\max }$ ratios $(<5)$, there was only one upward break. After starting to flood at point A (see Fig. 1), the liquid level did not 


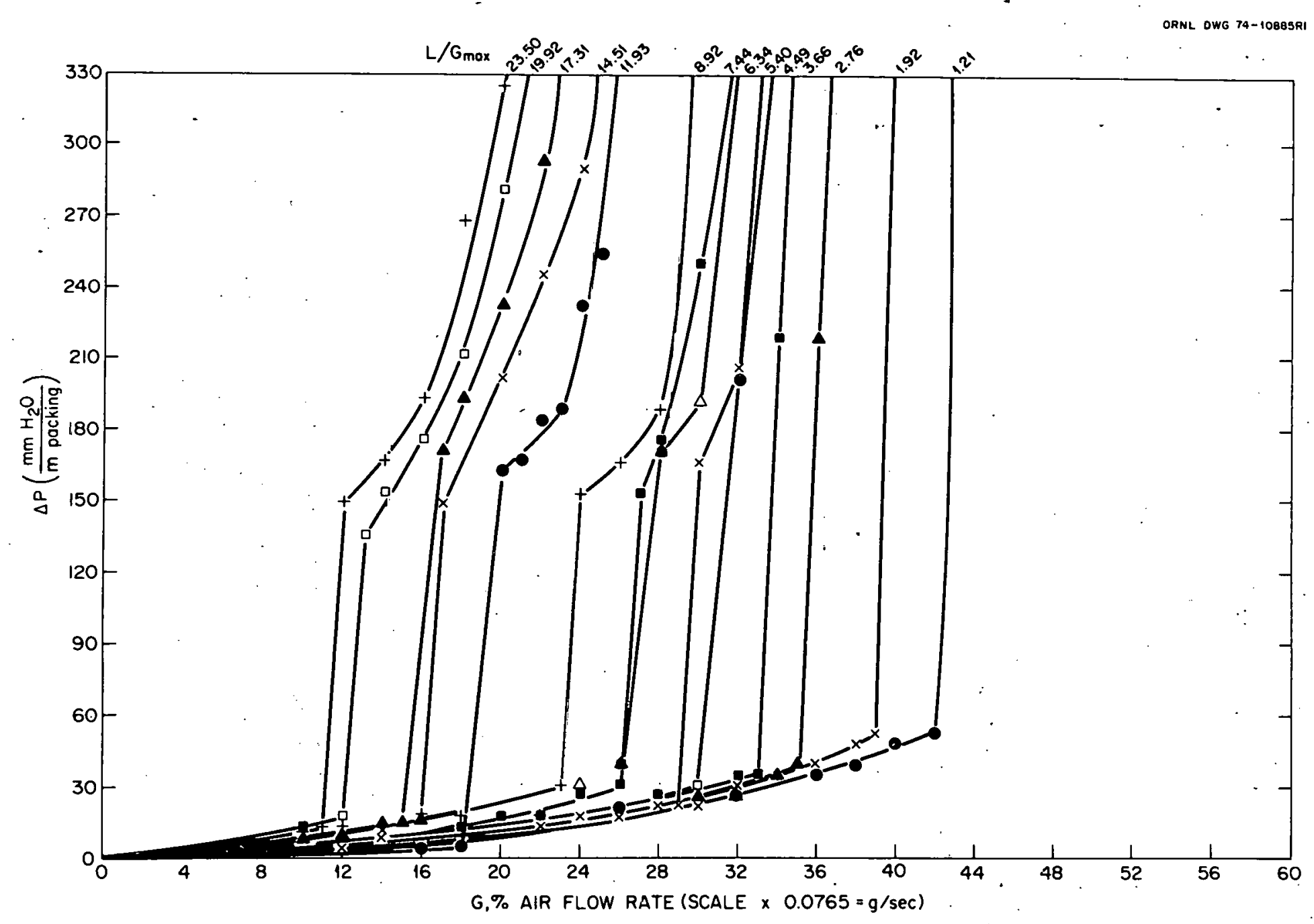

Fig. 4. Average pressure gradient across $23-\mathrm{cm}$ segment of $7.62-\mathrm{cm}$-diam Gocidloe packing during countercurrent flow of air and water. 
stabilize but, instead, continued upward until the entire column flooded. In this region, a slight decrease in the air rate from $G_{\max }$ caused the column to completely "deflood"; this was unlike the behavior observed at high $L / G_{\max }$ ratios, where a large decrease in the air flow rate was required to deflood the column.

\subsection{Inverted Column}

Since flooding always started at the same place (A) in the original" column, a flow constriction at that point was suspected. To verify this, the column was inverted $180^{\circ}$. In the resulting rearrangement, packing sections 1 and 12 had to be removed; therefore, the modified column was as shown in Fig. 2 .

The column was expected to flood at the same point and at the same flow rates as recorded for the original column. As anticipated, localized flooding did start at point A (see Fig. 2); surprisingly, however, the flooding rate, $G_{\max }$, was almost twice the rate observed in the original column. It is possible that in the process of inverting the column and removing some packing, the packing at the junction between sections 10 and 11 was loosened sufficiently to prevent flooding until higher air rates were attained. The results, however, continued to suggest that a constriction existed at junction A. On the other hand, no irregularity was visually evident when the top section of packing was removed. New sections of packing, 13 and 14, were then inserted into the column to replace the top two sections.

In subsequent experiments at low $\mathrm{L} / \mathrm{G}$ ratios, the column flooded at approximately the same flow rates, but flooding appeared to initiate at the water distributor cap. This cap was then replaced with a more open 
four-prong device to ensure that flooding was not caused by the distributor. Data obtained after the new device had been installed agreed with the earlier results; flooding again started within the column.

The results appeared to be quite similar to those shown in Fig. 4 for $L / G_{\max }$ ratios less than 5. No plateau was observed in the $\Delta \mathrm{P}-\mathrm{Vs}-\mathrm{G}$ curve for any $L / G_{\max }$ ratio in the range tested, 1.25 to 40 (see Table 3 in Appendix C). Once local flooding started (always at point A) within the inverted column, it would continue until the entire column was flooded. Liquid accumulation would appear first at point $A$, next at the junction between packing sections 5 and 6 , and finally spread throughout the column.

\section{3 Column with New Packing}

The entire column was repacked with new Goodloe packing in an effort to determine the effects of packing installation technique and apparent density. The new packing was sized and weighed along with the original packing that was removed; the results are presented in Tables 1 and 2. Thus, measurements were made of the new material before it was inserted into the column, while measurements were made of the original packing after its removal from the column. This may account for the large differences between the average heights and diameters of the two batches of packing. Note that the average mass of a packing section in the two groups is simflar (overlan within one standard deviation), but the average heights and diameters are different. This indicates that the original packing suffered both axial and radial compression. While radial compresstuni is unavoidable, an attempt was made during the repacking of the column to minimize axial compression. 
A comparison of Figs. 2 and 3 shows the apparent density of this new packing arrangement was much lower than that for the inverted column arrangement. Whereas ten packing sections were previously used for an apparent density of $0.53 \mathrm{~g} / \mathrm{cm}^{3}$, nine sections occupied the same volume in the new arrangement, resulting in an apparent density of only $0.49 \mathrm{~g} / \mathrm{cm}^{3}$ (see Appendix A). The results obtained using the new packing were, again, quite similar to those for the inverted column and are given in Table 4 (see Appendix C) for comparison. Flooding started at the junction between packing sections S-23 and S-25 and quickly progressed to the top of the column.

\section{COMPARISON OF EXPERIMENTAL DATA WITH MANUFACTURFR'S CORRELATION}

Figure 5 shows a $l o g-l o g$ plot of $G_{\max }$ vs $L / G_{\max }$ for the experimental data obtained in this study. The manufacturer's flooding correlation, 4 which was reported in the same manner (see Appendix B), is also presented for comparison. As may be seen, the flooding rates from the original column were only about one-half of those predicted by the Goodloe correlation over the range studied. Higher values were obtained for the inverted column so that the experimental data for $\mathrm{L} / \mathrm{G}_{\max }$ ratios greater than 10 agree well with the Goodloe correlation; however, at lower $\mathrm{L} / \mathrm{G}_{\max }$ ratios, the experimental data fell significantly below the correlation. For example, at an $L / G_{\max }$ ratio of $I$, the maximum air flow in the inverted column was only two-thirds of that predicted by the manufacturer's flooding correlation. Results obtained by using the new Goodloe packing were in good agreement with the inverted column data (within $\sim 5 \%$ ). 


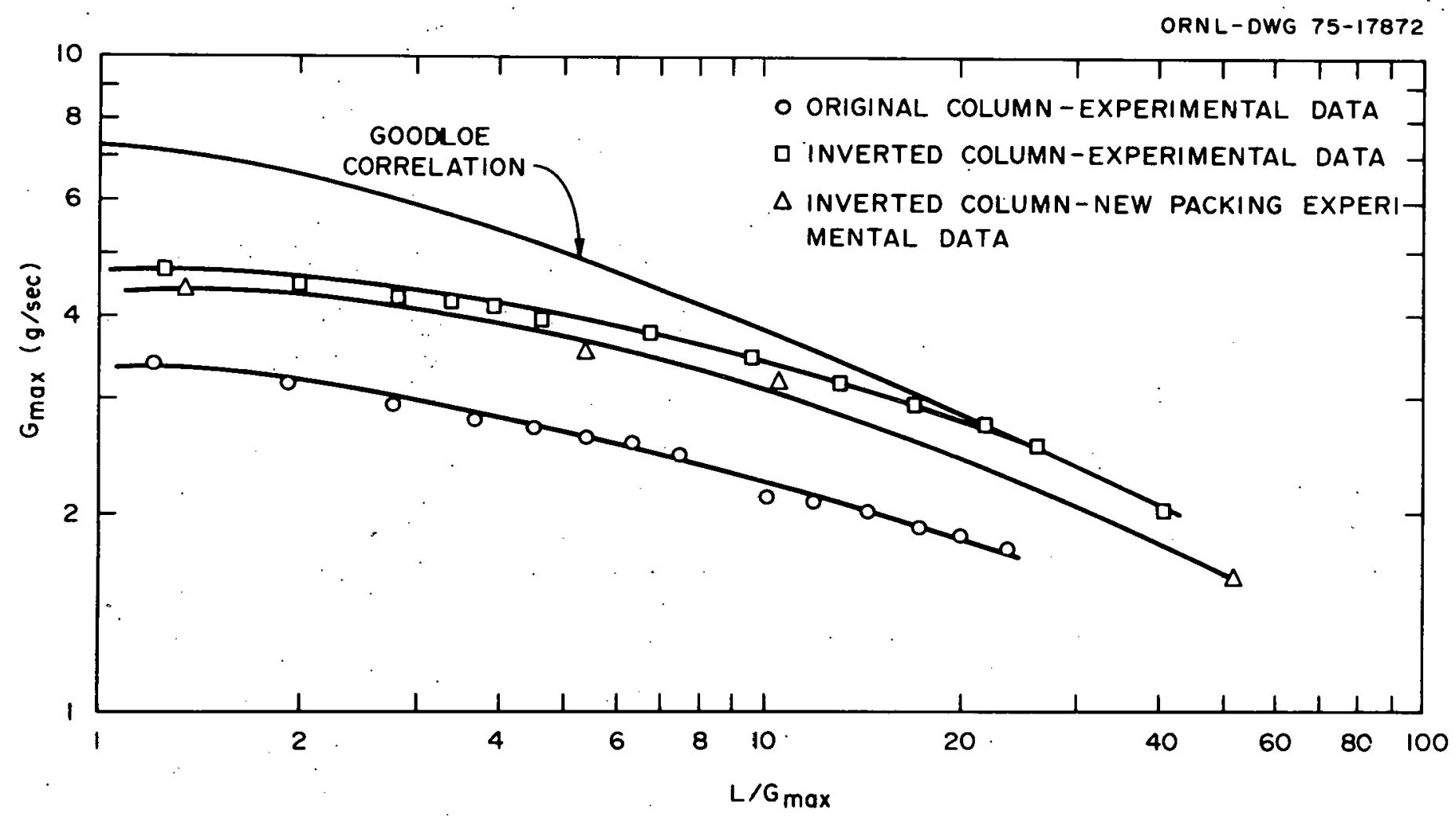

Fig. 5. Comparison of experimental measurements of air-water flooding rates in $7.62-\mathrm{cm}$-diam Goodloe packing with flooding rates predicted by tie manufacturer. 
The low values comprising the bottom curve (i.e., that for the original column) may have been the result of the method used to pack the column initially. The average height of a packing section was $11.4 \mathrm{~cm}$ in the original column, as compared with $14.0 \mathrm{~cm}$ after removal from the column; this indicates that the original packing underwent significant axial compression. Inverting the column and rearranging several sections allowed the packing to loosen so that the flooding capacity increased. This explanation, however, does not explain why the flooding rate in the column filled with new packing (apparent packing density $=0.49 \mathrm{~g} / \mathrm{cm}^{3}$ and no axial compression) was similar to that found in the inverted column (apparent packing density $=0.53 \mathrm{~g} / \mathrm{cm}^{3}$ and packing axially compressed from an average of $14.0 \mathrm{~cm}$ to $12.7 \mathrm{~cm}$ ).

\section{CONCLUSIONS}

The experimental data obtained in this study and their comparison with the manufacturer's correlation lead us to conclude that the flooding behavior of a column containing Goodloe packing can be difficult to predict. Thus, scale-up from either bench-scale data or the Goodloe correlation may be unreliable. Since much of the scatter in the results may be associated with the method used to pack the column, special care must be taken in this step. Based on the results presented in this report, we would expect the air-water flooding curve for a column with properly installed packing to more closely resemble the curve observed for the new column (or the similar curve for the inverted column studied previously) than that of the Goodloe correlation. However, it is highly improbable that exact packing properties can be reproduced each time 
the column is filled; allowance for at least $30 \%$ scatter from the most likely curve is recommended, as indicated by Fig. 5.

\section{REFERENCES}

1. Goodloe Column Packing, Bulletin No. G-702, Packed Column Company, Division Metex Corp., Edison, N. J.

2. I. B. Bragg, "Goodloe Column Packing," Ind. Eng. Chem. 49(7), 1062 (1957).

3. S. R. M. Ellis, K. E. Porter, and M. C. Jones, "A High Efficiency, Low Pressure-Drop Distillation Packing," Trans. Instn. Chem. Engrs. 41, 212 (1963).

4. Packed Column Information Bulletin, Packed Column Company, Division Metex Corp.; Edison, N. J. 
THIS PAGE

WAS INTENTIONALLY

LEFT BLANK 
8. APPENDIXES 
THIS PAGE

\section{WAS INTENTIONALLY LEFT BLANK}


8.1 Appendix A; Size and Density of Goodloe Packing

Tables $I$ and 2 . show the physical characteristics of the Goodloe packing in the original experimental column and that from a new shipment, respectively. Note that the average density of the original column packing was $0.4639 \mathrm{~g} / \mathrm{cc}$ as compared with an average density of 0.4182 $\mathrm{g} / \mathrm{cc}$ for the replacement sections. The nine replacement sections used (see Fig. 3) were those which had masses nearest the average value of $326.81 \mathrm{~g}$. They were selected on the basis of similar mass rather than density because each section on placement in the column was radially compressed to the diameter of $7.62 \mathrm{~cm}$ and was often also slightly compressed in the axial direction. Consequently, each section occupied approximately the same volume and had a density that varied in direct proportion to its mass.

The apparent packing density of the column was calculated from the. column volume occupied by packing and the mass of each section in the column, as shown below. For the original column:

$$
\begin{aligned}
\text { Volume } & =\pi R^{2} \mathrm{~h}=\pi(7.62 \mathrm{~cm} / 2)^{2} \quad(50 \mathrm{in.} \cdot 2.54 \mathrm{~cm} / \mathrm{in} .) \\
& =5791.67 \mathrm{~cm}^{3} \\
\text { Mass } & =\sum_{i=2}^{9} \text { Mass }_{i}+\sum_{1=13}^{14} \text { Mass }_{i}=3077.7 \mathrm{~g} \\
\therefore \rho_{\text {apparent }} & =3077.7 / 5791.67=0.5314 \mathrm{~g} / \mathrm{cm}^{3}
\end{aligned}
$$


For the column with new packing:

$$
\begin{aligned}
\text { Volume }= & \pi \mathrm{R}^{2} \mathrm{~h}=\pi(7.62 \mathrm{~cm} / 2)^{2}(132 \mathrm{~cm}) \\
= & 6023.33 \mathrm{~cm}^{3} \\
\text { Mass }= & \text { Mass of }(\mathrm{S} 4+\mathrm{S} 23+\mathrm{S} 25+\mathrm{S} 19+\mathrm{S} 27+\mathrm{S} 13+\mathrm{S} 24+ \\
= & 2937.1 \mathrm{~g} \\
\therefore \rho_{\text {apparent }}= & 2937.1 / 6023.33=0.4876 \mathrm{~g} / \mathrm{cm}^{3}
\end{aligned}
$$


Table 1. Size and density measurements of Goodloe packing from the original column segments

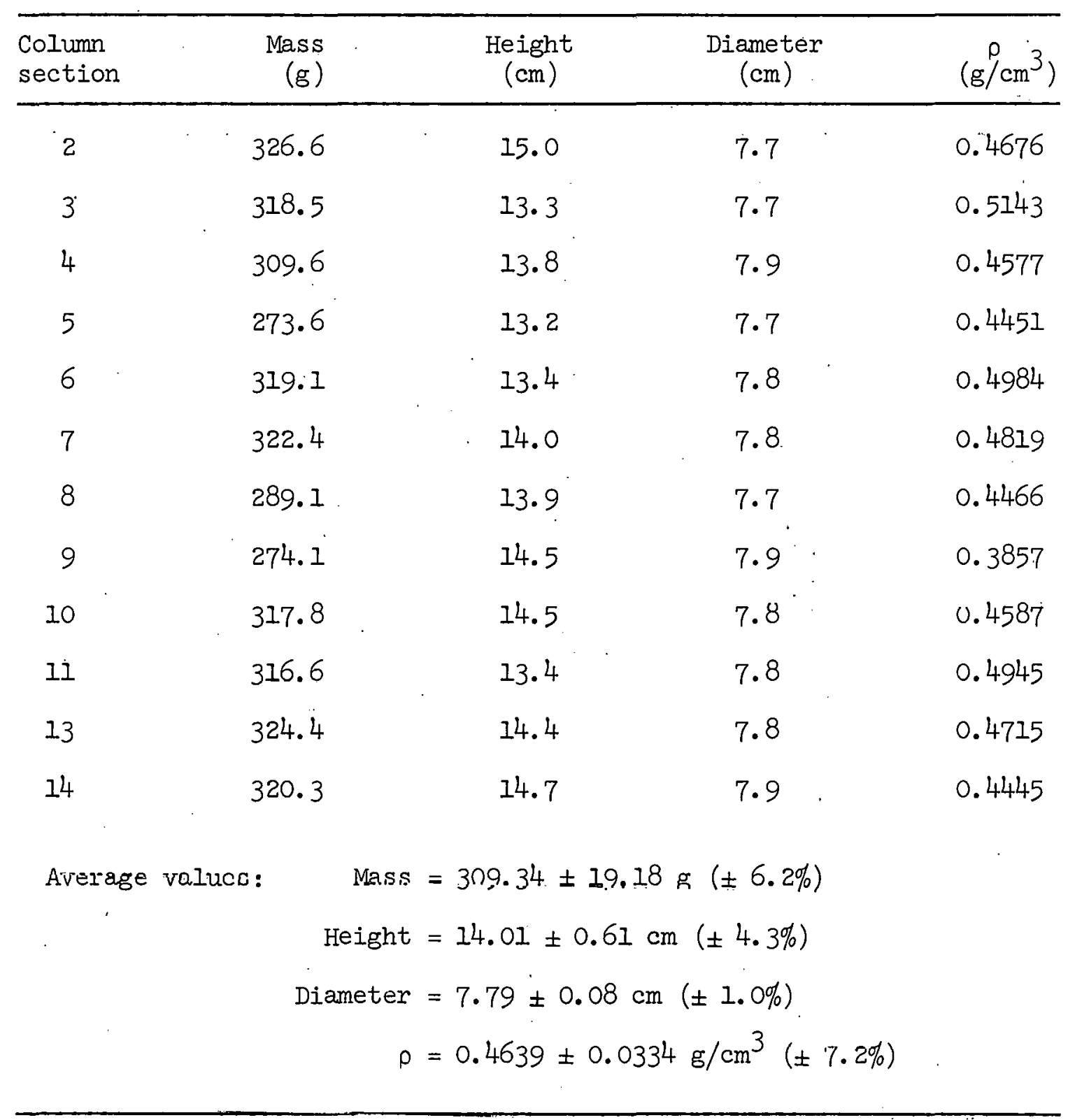


Table 2. Size and density measurements of Goodloe packing from a new shipment

\begin{tabular}{|c|c|c|c|c|}
\hline $\begin{array}{l}\text { Column } \\
\text { section } \\
\text { number }\end{array}$ & $\begin{array}{r}\text { Mass } \\
(\mathrm{g})\end{array}$ & $\begin{array}{l}\text { Height } \\
(\mathrm{cm})\end{array}$ & $\begin{array}{l}\text { Diameter } \\
(\mathrm{cm})\end{array}$ & $\left.\stackrel{\rho}{\rho} \mathrm{cm}^{3}\right)$ \\
\hline 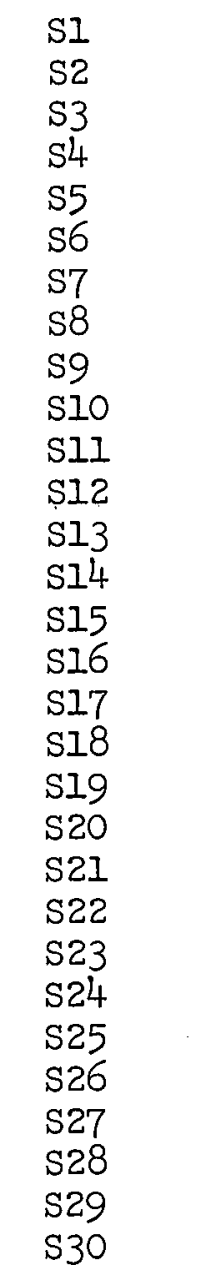 & $\begin{array}{l}315.3 \\
316.0 \\
305.1 \\
326.5 \\
316.0 \\
315.3 \\
307.8 \\
320.6 \\
310.8 \\
334.9 \\
339.5 \\
365.2 \\
329.6 \\
308.9 \\
305.3 \\
357.2 \\
340.7 \\
340.3 \\
328.1 \\
303.5 \\
323.5 \\
318.9 \\
327.6 \\
320.4 \\
328.1 \\
343.2 \\
332.7 \\
340.0 \\
341.5 \\
341.8\end{array}$ & $\begin{array}{l}15.0 \\
14.7 \\
14.8 \\
14.9 \\
14.9 \\
14.7 \\
15.2 \\
15.0 \\
15.0 \\
14.8 \\
15.0 \\
15.0 \\
15.2 \\
14.7 \\
14.8 \\
15.0 \\
14.9 \\
14.8 \\
14.8 \\
14.8 \\
15.1 \\
14.8 \\
14.8 \\
14.8 \\
14.8 \\
14.6 \\
14.8 \\
14.7 \\
14.8 \\
14.8\end{array}$ & $\begin{array}{l}8.0 \\
8.1 \\
7.8 \\
8.6 \\
8.3 \\
8.4 \\
7.8 \\
8.2 \\
8.0 \\
8.3 \\
8.4 \\
8.7 \\
8.2 \\
7.8 \\
8.0 \\
8.5 \\
8.3 \\
8.4 \\
8.1 \\
7.8 \\
7.9 \\
8.1 \\
8.3 \\
8.0 \\
8.1 \\
8.4 \\
8.3 \\
8.4 \\
8.2 \\
8.1\end{array}$ & $\begin{array}{l}0.4182 \\
0.4172 \\
0.4314 \\
0.3772 \\
0.3920 \\
0.3870 \\
0.4238 \\
0.4047 \\
0.4122 \\
0.4182 \\
0.4084 \\
0.4096 \\
0.4106 \\
0.4398 \\
0.4104 \\
0.4197 \\
0.4226 \\
0.4149 \\
0.4302 \\
0.4292 \\
0.4371 \\
0.4182 \\
0.4091 \\
0.4307 \\
0.4302 \\
0.4242 \\
0.4155 \\
0.4174 \\
0.4369 \\
0.4482\end{array}$ \\
\hline \multicolumn{5}{|c|}{$\begin{aligned} \text { Height } & =14.87 \pm 0.15 \mathrm{~cm}( \pm 1 \%) \\
\text { Mass } & =326.81 \pm 15.54 \mathrm{~g}( \pm 4.8 \%) \\
\text { iameter } & =8.18 \pm 0.24 \mathrm{~cm}( \pm 2.9 \%)\end{aligned}$} \\
\hline
\end{tabular}


8.2 Appendix B: Use of the Goodloe Correlation

For a gas-liquid system, the capacity of Goodloe packing is expressed by the following equation: ${ }^{4}$

$$
U_{\max }=\frac{2.8712}{\mu}\left[\frac{\rho_{I-33} \rho_{G}}{\rho_{G}}\right]^{0.57},
$$

where

$$
\begin{aligned}
U_{\text {max }} & =\text { uncorrected maximum gas velocity, } \mathrm{cm} / \mathrm{sec}, \\
\mu & =\text { liquid viscosity, } \mathrm{cP} \\
\rho_{\mathrm{I}} & =\text { liquid density, } \mathrm{g} / \mathrm{cm}^{3} \\
\rho_{\mathrm{G}} & =\text { gas density, } \mathrm{g} / \mathrm{cm}^{3} .
\end{aligned}
$$

For water and air:

$$
\begin{aligned}
\mu & =1.0 \mathrm{cP}, \\
\rho_{L} & =1.0 \mathrm{~g} / \mathrm{cm}^{3}, \\
\rho_{G} & =0.001202 \mathrm{~g} / \mathrm{cm}^{3} ;
\end{aligned}
$$

then from Eq. (I):

$$
U_{\max }=132.5 \mathrm{~cm} / \mathrm{ser} .
$$

For $L / G$ ratios not equal to $1, U_{\max }$ is corrected by the use of Fig. 6 (provided by the manufacturer). For example, an $L / G$ of 7.0 yields a correction ractor of 0.60 . Then;

$$
\begin{aligned}
U_{\max } \text { corr } & =\text { correction factor } U_{\max } \\
& =0.60 \cdot 132.5=79.5 \mathrm{~cm} / \mathrm{sec} .
\end{aligned}
$$


ORNL-DWG 75-17873

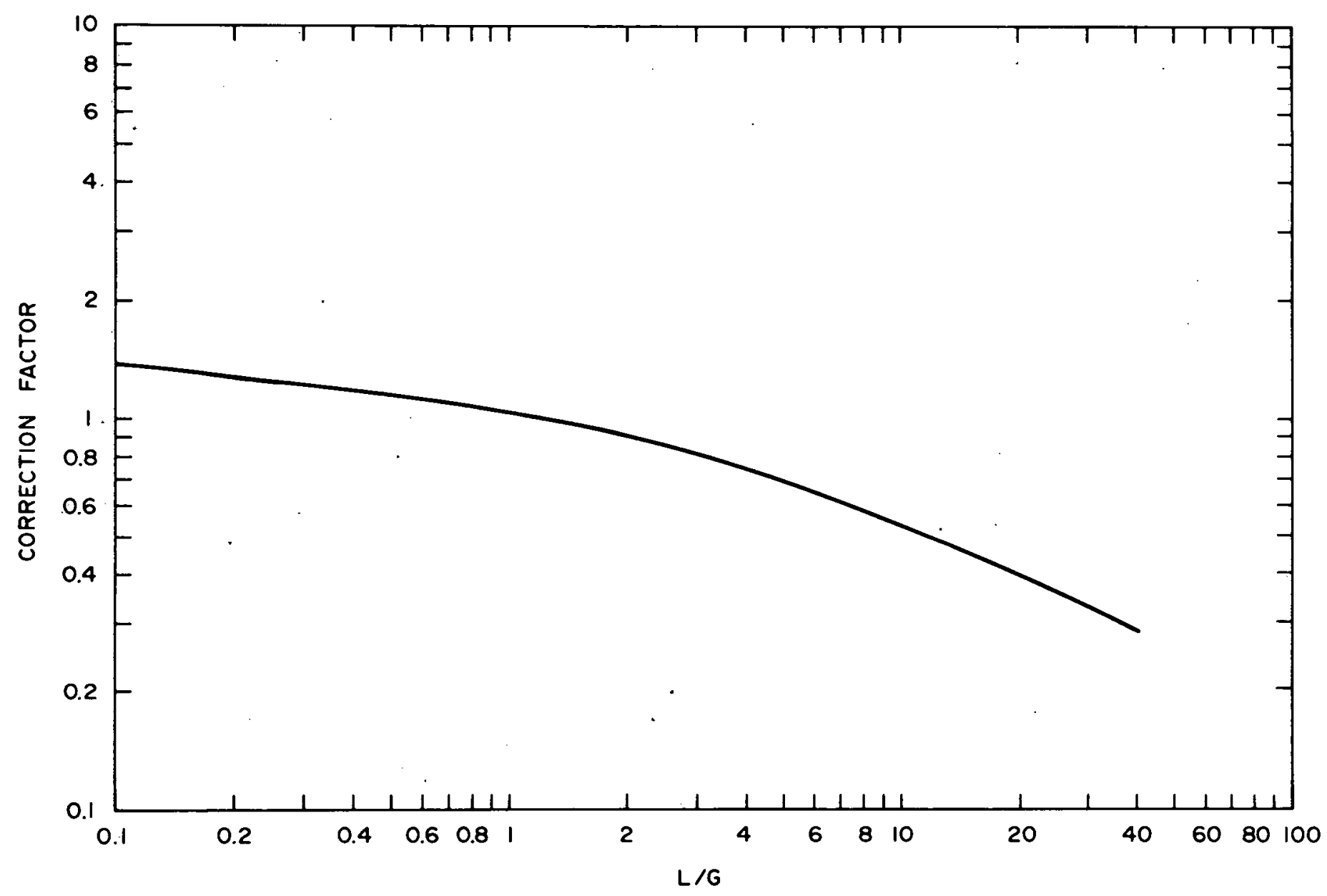

Fig. 6. Correction curve supplied by the Packed Column Company. 
The maximum corrected velocity is converted to a maximum mass flow rate, 'max' by the following equation:

$$
G_{\max }=U_{\max , \operatorname{corr}} \cdot A \cdot \rho_{G} \text {, }
$$

where

$$
A=\text { column cross-sectional area, } \mathrm{cm}^{2} \text {. }
$$

For the 7.62-cm-diam column:

$$
\begin{aligned}
G_{\max } & =79.5 \frac{\mathrm{cm}}{\mathrm{sec}} \cdot \pi(7.62 \mathrm{~cm} / 2)^{2} \cdot 0.001202 \frac{\mathrm{g}}{\mathrm{cm}^{3}} \\
& =4.36 \mathrm{~g} / \mathrm{sec} .
\end{aligned}
$$

Thus, the Goodloe correlation shown in Fig. 5 was obtained by:
(1) choosing an L/G ratio,
(2) determining the correction factor from Fig. 6,
(3) calculating $U_{\max }$, corr by Eq. (2),
(4) calculating $G_{\max }$ by Eq. (3),
(5) plotting $G_{\max }$ vs the chosen $L / G$ ratio. 


\section{THIS PAGE}

\section{WAS INTENTIONALLY \\ LEFT BLANK}


8:3 Appendix C: Pressure Drop Throughout the Column vs Air Flow Rate

Figure 4 shows the pressure drop between pressure taps P-3 and P-5 from the original column as a function of gas flow velocity. Since local flooding occurred near the bottom of this column, pressure drops across higher column sections were small and not measured. When the column was inverted, however, flooding started near the top of the column; consequentIy, significant pressure drops could be measured throughout the entire column. The results of these measurements on the inverted column and the column with new packing are presented in Tables 3 and 4. Each section in the tables corresponds to a constant water. flow rate; the air flow rate was incrementally increased until flooding occurred. The pressure gradient was approximately uniform over the various segments of the column. 
Table 3. Pressure drop measurements with the inverted column

\begin{tabular}{|c|c|c|c|c|c|c|}
\hline \multirow{2}{*}{$\begin{array}{c}\mathrm{L} \\
\left(\mathrm{g} \mathrm{H}_{?} \mathrm{O} / \mathrm{sec}\right)\end{array}$} & \multirow{2}{*}{$\begin{array}{c}\mathrm{G}, \\
\text { rotameter } \\
\text { setting }^{\mathrm{a}}\end{array}$} & & \multicolumn{4}{|c|}{$\mathrm{mm}_{2} \mathrm{O} / 23 \mathrm{~cm}$ of packing ${ }^{\mathrm{b}}$} \\
\hline & & & $\Delta \mathrm{P}_{1}$ & $\Delta \mathrm{P}_{2}$ & $\Delta \mathrm{P}_{3}$ & $\Delta \mathrm{P}_{4}$ \\
\hline 81.87 & $\begin{array}{l}20 \\
22 \\
24 \\
25\end{array}$ & & $\begin{array}{l}9 \\
4 \\
6 \\
*\end{array}$ & $\begin{array}{l}2 \\
8 \\
6 \\
*\end{array}$ & $\begin{array}{l}2 \\
2 \\
5 \\
*\end{array}$ & $\begin{array}{r}3 \\
4 \\
17 \\
. *\end{array}$ \\
\hline 66.17 & $\begin{array}{l}24 \\
26 \\
28 \\
30 \\
32\end{array}$ & & $\begin{array}{l}4 \\
6 \\
6 \\
8 \\
*\end{array}$ & $\begin{array}{l}6 \\
6 \\
8 \\
8 \\
*\end{array}$ & $\begin{array}{l}4 \\
5 \\
5 \\
7 \\
*\end{array}$ & $\begin{array}{l}4 \\
4 \\
5 \\
6 \\
*\end{array}$ \\
\hline 59.16 & $\begin{array}{l}20 \\
24 \\
26 \\
28 \\
30 \\
32 \\
33 \mathrm{~d} \\
34\end{array}$ & & $\begin{array}{l}3 \\
4 \\
4 \\
4 \\
5 \\
8 \\
8 \\
*\end{array}$ & $\begin{array}{l}4 \\
4 \\
4 \\
4 \\
6 \\
8 \\
8 . \\
* \\
*\end{array}$ & $\begin{array}{l}3 \\
5 \\
5 \\
6 \\
7 \\
7 \\
8 \\
*\end{array}$ & $\begin{array}{r}2 \\
3 \\
4 \\
4 \\
5 \\
10 \\
11 \\
*\end{array}$ \\
\hline 49.67 & $\begin{array}{l}20 \\
24 \\
26 \\
28 \\
30 \\
32 \\
34 \\
35 \\
36 \\
37^{d}\end{array}$ & & $\begin{array}{r}4 \\
4 \\
4 \\
4 \\
5 \\
6 \\
10 \\
10 \\
9 \\
*\end{array}$ & $\begin{array}{r}3 \\
3 \\
3 \\
4 \\
6 \\
7 \\
8 \\
8 \\
15 \\
*\end{array}$ & $\begin{array}{r}2 \\
4 \\
5 \\
5 \\
5 \\
7 \\
7 \\
8 \\
13 \\
*\end{array}$ & $\begin{array}{r}3 \\
3 \\
4 \\
5 \\
5 \\
5 \\
18 \\
22 \\
26 \\
*\end{array}$ \\
\hline 41.68 & $\begin{array}{l}20 \\
24 \\
28 \\
32 \\
34 \\
36 \\
38 \\
39{ }_{d} \\
40\end{array}$ & $0^{\circ}$ & $\begin{array}{r}3 \\
5 \\
5 \\
6 \\
7 \\
8 \\
10 \\
14 \\
*\end{array}$ & $\begin{array}{r}2 \\
1 \\
2 \\
5 \\
8 \\
8 \\
11 \\
15 \\
*\end{array}$ & $\begin{array}{r}2 \\
4 \\
5 \\
6 \\
7 \\
8 \\
10 \\
12 \\
*\end{array}$ & $\begin{array}{r}3 \\
3 \\
4 \\
6 \\
7 \\
9 \\
15 \\
39 \\
*\end{array}$ \\
\hline 33.33 & $\begin{array}{l}30 \\
34 \\
38 \\
40 \\
42 \\
43 \\
44\end{array}$ & & $\begin{array}{r}4 \\
6 \\
10 \\
9 \\
14 \\
15 \\
*\end{array}$ & $\begin{array}{r}8 \\
10 \\
14 \\
13 \\
12 \\
16 \\
*\end{array}$ & $\begin{array}{r}4 \\
5 \\
5 \\
10 \\
14 \\
13 \\
*\end{array}$ & $\begin{array}{r}4 \\
6 \\
9 \\
11 \\
14 \\
19 \\
*\end{array}$ \\
\hline
\end{tabular}


Table 3 (continued)

\begin{tabular}{|c|c|c|c|c|c|}
\hline \multirow{2}{*}{$\left(\mathrm{g} \mathrm{H}_{2}^{\mathrm{L}} \mathrm{O} / \mathrm{sec}\right)$} & \multirow{2}{*}{$\begin{array}{c}\mathrm{G}, \\
\text { rotameter } \\
\text { setting }\end{array}$} & \multicolumn{4}{|c|}{$\mathrm{mm} \mathrm{H}_{2} \mathrm{O} / 23 \mathrm{~cm}$ of packing ${ }^{\mathrm{b}}$} \\
\hline & & $\Delta \mathrm{P}_{1}$ & $\Delta \mathrm{P}_{2}$ & $\Delta \mathrm{P}_{3}$ & $\Delta \mathrm{P}_{4}$ \\
\hline 18.33 & $\begin{array}{l}46 \\
48 \\
50^{d} \\
51\end{array}$ & $\begin{array}{r}17 \\
1.5 \\
22 \\
*\end{array}$ & $\begin{array}{r}15 \\
1.7 \\
21 \\
\times\end{array}$ & $\begin{array}{r}14 \\
1.7 \\
19 \\
x\end{array}$ & $\begin{array}{l}16 \\
17 \\
21 \\
x\end{array}$ \\
\hline 16.27 & $\begin{array}{l}48 \\
50 \\
52 \mathrm{~d} \\
53\end{array}$ & $\begin{array}{l}16 \\
20 \\
23 \\
*\end{array}$ & $\begin{array}{r}18 \\
21 \\
24 \\
*\end{array}$ & $\begin{array}{r}16 \\
19 \\
22 \\
*\end{array}$ & $\begin{array}{l}16 \\
19 \\
22 \\
*\end{array}$ \\
\hline 14.24 & $\begin{array}{l}50 \\
52 \\
54\end{array}$ & $\begin{array}{r}15 \\
.22 \\
*\end{array}$ & $\begin{array}{r}20 \\
24 \\
*\end{array}$ & $\begin{array}{r}19 \\
21 \\
*\end{array}$ & $\begin{array}{r}18 \\
22 \\
*\end{array}$ \\
\hline 12.06 . & $\begin{array}{l}40 \\
44 \\
48 \\
52 \\
53 \\
54 \\
55\end{array}$ & $\begin{array}{r}8 \\
10 \\
15 \\
24 \\
27 \\
27 \\
*\end{array}$ & $\begin{array}{r}9 \\
8 \\
15 \\
20 \\
22 \\
24 \\
*\end{array}$ & $\begin{array}{r}8 \\
12 \\
16 \\
21 \\
22 \\
25 \\
*\end{array}$ & $\begin{array}{r}8 \\
10 \\
15 \\
20 \\
21 \\
23 \\
*\end{array}$ \\
\hline 8.94 & $\begin{array}{l}50 \\
52 \\
54 \\
55 \\
56 \\
57 \\
58 \mathrm{~d}\end{array}$ & $\begin{array}{r}17 \\
20 \\
24 \\
24 \\
26 \\
27 \\
*\end{array}$ & $\begin{array}{r}19 \\
20 \\
23 \\
26 \\
27 \\
29 \\
*\end{array}$ & $\begin{array}{r}17 \\
20 \\
23 \\
23 \\
26 \\
27 \\
*\end{array}$ & $\begin{array}{r}16 \\
18 \\
20 \\
22 \\
24 \\
25 \\
*\end{array}$ \\
\hline 5.90 & $\begin{array}{l}56 \\
58 \\
60 \mathrm{~d} \\
61\end{array}$ & $\begin{array}{r}23 \\
26 \\
31 \\
*\end{array}$ & $\begin{array}{r}27 \\
31 \\
34 \\
*\end{array}$ & $\begin{array}{l}23 \\
26 \\
31 \\
. *\end{array}$ & $\begin{array}{r}20 \\
23 \\
26 \\
*\end{array}$ \\
\hline
\end{tabular}

Where

a.Kotameter setting $\times$ U.0'/6́s $=\mathrm{g} / \mathrm{sec}$ of air.

${ }^{\mathrm{b}} \Delta \mathrm{P}_{1}=\mathrm{P}_{0}-\mathrm{P}_{5}$ (nm $\mathrm{H}_{\mathrm{z}} \mathrm{O} / 23 \mathrm{~cm}$ of packing), $\Delta \mathrm{P}_{2}=\mathrm{P}_{5}-\mathrm{P}_{6}\left(\mathrm{~mm} \mathrm{H}_{2} \mathrm{O} / 23 \mathrm{~cm}\right.$ of packing $)$, $\Delta \mathrm{P}_{3}=\mathrm{P}_{6}-\mathrm{P}_{7}\left(\mathrm{~mm} \mathrm{H}_{2} \mathrm{O} / 38 \mathrm{~cm}\right.$ of packing $),{ }^{\mathrm{c}}$ $\Delta \mathrm{P}_{4}=\mathrm{P}_{7}-\mathrm{P}_{8} \cdot\left(\mathrm{mm} \mathrm{H}_{2} \mathrm{O} / 23 \mathrm{~cm}\right.$ of packing $)$.

To convert $\Delta \mathrm{P}_{3}$ to $\mathrm{mm} \mathrm{H}_{2} \mathrm{O} / 23 \mathrm{~cm}$ of packing, its value was multiplied by 0.60 .

$\mathrm{d}_{\mathrm{G}_{\max }}$; column flooded, pressure drop measurements not meaningful. 
Table 4. Pressure drop measurements on new packing in the inverted column

\begin{tabular}{|c|c|c|c|c|c|}
\hline \multirow{2}{*}{$\begin{array}{c}\mathrm{L} \\
\left(\mathrm{g} \mathrm{H}_{2} \mathrm{O} / \mathrm{sec}\right)\end{array}$} & \multirow{2}{*}{$\begin{array}{c}\mathrm{G}, \\
\text { rotameter } \\
\text { setting }\end{array}$} & & \multicolumn{3}{|c|}{$\mathrm{mm} \mathrm{H}_{2} \mathrm{O} / 23 \mathrm{~cm}$ of packing ${ }^{\mathrm{b}}$} \\
\hline & & $\Delta \mathrm{P}_{1}$ & $\Delta \mathrm{P}_{2}$ & $\Delta \mathrm{P}_{3}$ & $\Delta \mathrm{P}_{4}$ \\
\hline 81.87 & $\begin{array}{l}12 \\
14 \\
16 \\
18 \\
20\end{array}$ & $\begin{array}{l}1 \\
1 \\
2 \\
3 \\
*\end{array}$ & $\begin{array}{l}2 \\
2 \\
3 \\
2 \\
*\end{array}$ & $\begin{array}{l}1 \\
2 \\
2 \\
3 \\
*\end{array}$ & $\begin{array}{l}2 \\
2 \\
4 \\
7 \\
*\end{array}$ \\
\hline 33.33 & $\begin{array}{l}20 \\
24 \\
28 \\
32 \\
36 \\
38 \mathrm{a} \\
40\end{array}$ & $\begin{array}{l}3 \\
3 \\
3 \\
4 \\
5 \\
8 \\
*\end{array}$ & $\begin{array}{l}1 \\
0 \\
0 \\
2 \\
4 \\
4 \\
*\end{array}$ & $\begin{array}{l}1 \\
3 \\
4 \\
4 \\
5 \\
8 \\
*\end{array}$ & $\begin{array}{r}3 \\
3 \\
4 \\
6 \\
9 \\
13 \\
*\end{array}$ \\
\hline 18.81 & $\begin{array}{l}40 \\
42 \\
43 \\
44 \\
45^{d}\end{array}$ & $\begin{array}{l}5 \\
5 \\
6 \\
7 \\
*\end{array}$ & $\begin{array}{l}6 \\
8 \\
7 \\
8 \\
*\end{array}$ & $\begin{array}{l}7 \\
7 \\
8 \\
8 \\
*\end{array}$ & $\begin{array}{r}6 \\
8 \\
8 \\
11 \\
*\end{array}$ \\
\hline 5.90 & $\begin{array}{l}46 \\
48 \\
50 \\
52 \\
54 d \\
57\end{array}$ & $\begin{array}{r}8 \\
10 \\
10 \\
12 \\
14 \\
*\end{array}$ & $\begin{array}{r}7 \\
8 \\
9 \\
10 \\
16 \\
*\end{array}$ & $\begin{array}{r}8 \\
8 \\
10 \\
11 \\
10 \\
*\end{array}$ & $\begin{array}{r}9 \\
10 \\
12 \\
13 \\
15 \\
*\end{array}$ \\
\hline
\end{tabular}

Where

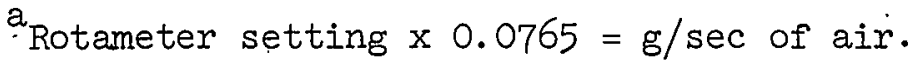

${ }^{\mathrm{b}} \mathrm{P}_{1}=\mathrm{P}_{3}-\mathrm{P}_{5}\left(\mathrm{~mm} \mathrm{H} \mathrm{H}_{2} \mathrm{O} / 23 \mathrm{~cm}\right.$ of packing $)$,

$\Delta \mathrm{P}_{2}=\mathrm{P}_{5}-\mathrm{P}_{6}\left(\mathrm{~mm} \mathrm{H}_{2} \mathrm{O} / 23 \mathrm{~cm}\right.$ of packing $)$,

$\Delta \mathrm{P}_{3}=\mathrm{P}_{6}-\mathrm{P}_{7}\left(\mathrm{~mm} \mathrm{H}_{2} \mathrm{O} / 38 \mathrm{~cm} \text { of packing }\right)^{\mathrm{C}}$

$\Delta \mathrm{P}_{4}=\mathrm{P}_{7}-\mathrm{P}_{8}\left(\mathrm{~mm} \mathrm{H}_{2} \mathrm{O} / 23 \mathrm{~cm}\right.$ of packing $)$.

co convert $\Delta \mathrm{P}_{3}$ to $\mathrm{mm} \mathrm{H}_{2} \mathrm{O} / 23 \mathrm{~cm}$ of packing, its value was multiplied by 0.60 .

$\mathrm{d}_{\mathrm{G}_{\text {max }}}$; column flooded, pressure drop measurements not meaningful. 
INTERNAL DISTRIBUTION

1-2. Central Research Library

3. Document Reference Section

4-6. Laboratory Records

7. Laboratory Records - RC

8. MIT Practice School

9. ORNL Patent Section

10-11. ORNL - Y-12 Technical Library

12-16. J. M. Begovich

17. K. B. Brown

18. F. I. Culler

19. D. E. Ferguson

20. C. W. Forsberg

21. J. B. Gibson

22. T. M. Gilliam

23. R. W. Glass

24. W. R. Grimes
25. W. S. Groenier

26-63. P. R. Kasten

64. J. A. Klein

65. K. J. Notz

66. H. Postma

67. A. D. Ryon

68. C. D. Scott

69. M. J. Stephenson

70. D. B. Trauger

71-75. J. S. Watson

76. R. G. Wymer

77. W. K. Davis (Consultant)

78. J. C. Frye (Consultant)

79. C. H. Ice (Consultant)

80. R. B. Richards (Consultant)

EXTERNAL DISTRIBUTION

81. W. J. Haubach, Division of Physical Research, ERDA, Washington, D. C. 20545

82. Research and Technical Support Division, ERDA-ORO, Oak Ridge, Tennessee 37830

83-109. Technical Information Center, Oak Ridge, Tennessee 37830 